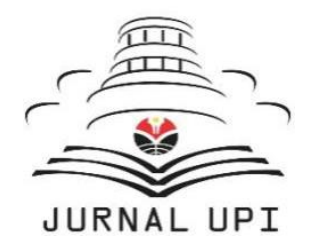

THE JOURNAL GASTRONOMY TOURISM

Volume 2 Nomor 1, Juni 2015, 8-12

Tersedia daring di:

https://ejournal.upi.edu/index.php/gastur

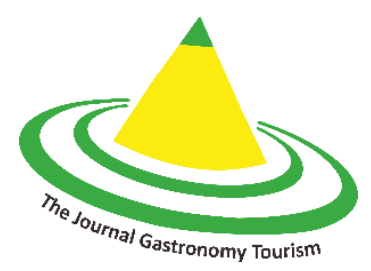

\title{
Strategi Pengembangan Bisnis Penjual Peuyeum Bendul Pasca Pandemic Covid-19 \\ (Studi Kasus di Kecamatan Sukatani Kabupaten Purwakarta)
}

\author{
Zulfa Nurwahidah, Agus Sudono, Risya Ladiva Bridha \\ Universitas Pendidikan Indonesia, Jl. Dr. Setiabudhi No. 229, Bandung 40154, Indonesia \\ *Korespondensi penulis, E-mail: zulfanurwahidah@upi.edu
}

\begin{abstract}
ABSTRAK
Penjual peuyeum bendul merupakan salah satu yang menjual produk oleh-oleh khas Kecamatan Sukatani Kabupaten Purwakarta. Produk utamanya adalah peuyeum bendul. Peuyeum bendul ini erbuat dari singkong atau ubi kayu dan dijual di sepanjang jalan nasional Kecamatan Sukatani. Penelitian ini bertujuan untuk mendeskripsikan dan menganalisa faktor internal dan eksternal yang dapat mempengaruhi penjualan peyeum bendul, serta untuk mengetahui strategi pengembangan bisnis yang perlu diterapkan oleh pelaku usaha peuyeum bendul guna meningkatkan penjualan produknya. Penelitian ini menggunakan pendekatan penelitian kualitatif, dimana penelitian ini diperoleh dari hasil wawancara terbuka atau mendalam dengan 20 partisipan (yaitu para penjual peuyeum bendul). Metode analisis data menggunakan analisis SWOT dan analisis matriks SWOT. Hasil dari penelitian ini menunjukkan bahwa alternatif strategi yang dapat diterapkan pada pengembangan bisnis penjual peuyeum bendul adalah pengembangan produk yaitu melakukan diferensiasi produk berbahan dasar peuyeum bendul, penjualan peuyeum bendul melalui media sosial, dan pengelolaan keuangan bisnis penjual peuyeum bendul.
\end{abstract}

Kata kunci: Strategi Pengembangan Bisnis, Porter's Five-Forces Model, Analisis SWOT, Matriks SWOT 


\section{Pendahuluan}

Indonesia memiliki banyak peninggalan sejarah dengan beranekaragam adat budaya dan seni dari masyarakat lokalnya, yang membuktikan bahwa Indonesia memiliki pesona alam yang begitu indah dan menjadi daya tarik wisatawan lokal maupun wisatawan mancanegara sebagai daerah tujuan wisata (Devy \& Soemanto, 2017, hal. 34)

\section{International Culinary Tourism} Association (ICTA) menjelaskan bahwa wisata kuliner pada saat ini harus berkonsentrasi bagaimana cara penyajian suatu makanan serta minuman dengan demikian wisatawan akan lebih tertarik untuk datang dan menikmatinya (Wulandari et al., 2019, hal. 390). Satu diantara beberapa kota atau kabupaten yang tersebar di Indonesia ini mempunyai makanan khas yang terkenal yaitu Peuyeum Bendul. Peuyeum bendul ditemukan pada tahun 1940 oleh seorang warga Desa Bendul bernama Pak Murdi (Hidayat \& Prasetyo, 2018, hal. 267). Bendul sendiri diambil dari nama daerah yang merupakan nama desa yang berada di Purwakarta Kecamatan Sukatani tempat dimana oleh-oleh khas ini diproduksi. Pusat oleh-oleh peuyeum bendul terletak di Jalan Raya Sukatani Kecamatan Sukatani Kabupaten Purwakarta. Peuyeum bendul dijual di kios-kios sepanjang jalan Raya Sukatani yang berada di daerah Bendul dengan cara memajang didepan kios dengan cara digantung agar dapat telihat jelas oleh para pembeli.

Peuyeum bendul menjadi ciri khas dari Purwakarta dan harus memiliki brand identify "Purwakarta Istimewa". Peyeum bendul belum memiliki brand identify atau tidak berlogo "Purwakarta Istimewa" (Hidayat \& Prasetyo, 2018, hal. 269). Dibandingkan dengan jajanan lainnya, peuyeum bendul menjadi salah satu makanan yang dicari wisatawan sebagai buah tangan untuk dibawa pulang ketika sedang berkunjung dan berwisata di Purwakarta atau sekedar melintasi jalur Sukatani Kabupaten Purwakarta.

Penjualan peuyeum di Desa Bendul pada tahun 2020 mengalami penurunan dalam penjualannya yang mengakibatkan kerugian serta total pendapatan berkurang hingga $20-40 \%$ dari tahun sebelumnya. Hal ini disebabkan karena adanya wabah virus Covid-19 yang telah melanda berbagai sektor di dalam dan luar negeri, salah satunya penjual peuyeum di Kecamatan Sukatani Kabupaten Purwakarta.

Pandemi Covid-19 memberikan tantangan untuk para pengusaha karena para pengusaha diharuskan membuat penyelesaian demi mengembangkan usaha yang sedang dijalankan agar tetap berjalan dan bangkit kembali. Sehingga, hal yang perlu dilakukan untuk memulihkan serta meminimalisir kerugian yang semakin besar adalah dengan melakukan berbagai upaya atau perancangan strategis, agar dapat menaikan kembali pendapatan pasca pandemi Covid-19.

\section{Studi Literatur}

\subsection{Pariwisata}

Pariwisata adalah suatu aktivitas atau kegiatan yang dilakukan seseorang atau dengan kelompok secara berpindah-pindah mengunjungi tempat yang satu dan tempat lainnya secara berulang untuk sementara waktu bertujuan hanya menikmati keindahan alam tidak untuk mencari nafkah (Revida et al., 2020, hal. 4).

\subsection{Wisata Kuliner}

Wisata kuliner ialah untuk memperoleh pengalaman yang berharga dengan cara melakukan kegiatan memasak berbagai macam santapan serta memakan makanan khas masingmasing wilayah (Kristiana et al., 2018, hal. 19). Peuyeum atau Tape Singkong

Peuyeum ataupun tape singkong ialah makanan yang dibuat dari singkong yang di fermentasi, peuyeum ataupun tape singkong ini nyatanya mempunyai perbandingan dari segi pembuatan, wujud serta tekstur.

Tape dari ubi kayu telah dibuat oleh banyak masyarakat di wilayah Indonesia, salah satunya peuyeum yang dibuat dari Jawa Barat dengan karakteristik yang tidak berair serta memiliki rasa yang lebih manis (Asnawi, 2013, hal. 57).

\subsubsection{Peuyeum Bendul}


Peuyeum ialah salah satu makanan khas masyarakat Desa Bendul Purwakarta yang terbuat dari singkong atau ketela pohon yang telah di fermentasi. Bapak Murdi merupakan orang yang telah menciptakan makanan khas dari Purwakarta ini pada tahun 1940, beliau merupakan masyarakat kampung Bendul (Hidayat \& Prasetyo, 2018, hal. 269).

\subsection{Manajemen Strategi}

Manajemen strategi menurut David (2020, hal. 5) adalah seni dan ilmu dari perumusan, pengaplikasian, dan melakukan evaluasi dari berbagai keputusan yang mengharuskan organisasi memperoleh tujuan. Tujuan dari manajemen strategi adalah untuk mengembangkan dan menciptakan peluang baru (Anggraeni et al., 2017, hal. 29).

\subsection{Analisis SWOT}

Menurut Fatimah (2020, hal. 7), Analisis SWOT ini merupakan salah satu metode yang digunakan untuk mengevaluasi kekuatan (strengths), kelemahan (weaknesses), peluang (opportunities), dan ancaman (threats) dalam spekulasi bisnis. Analisis SWOT dapat diterapkan dengan menganalisis dan mengelompokkan hal-hal yang dapat mempengaruhi keempat faktornya tersebut. Dengan demikian, hasil analisis dapat membentuk rencana strategi berdasarkan hasil analisis faktor-faktor strategis perusahaan.

\section{Metodologi Penelitian}

Penelitian ini bertujuan untuk mendapatkan strategi pengembangan bisnis di Pusat Oleh-Oleh Peuyeum Bendul yang bertempat di JL. Raya Sukatani Purwakarta, melalui wawancara kepada responden yaitu penjual peyeum bendul.

Hasil wawancara tersebut digunakan sebagai data analisis SWOT sehingga diperoleh strategi pengembangan bisnis peuyeum bendul pasca pandemic covid-19.

\section{Hasil dan Pembahasan}

4.1 Wawancara

Wawancara terbuka atau wawancara mendalam adalah suatu metode pengumpulan data dengan menggunakan metode kualitatif. Berikut merupakan ringkasan hasil wawancara yang didapat dari 20 penjual Peuyeum Bendul.

Poin-poin hasil wawancara sebagai berikut

a. Alasan para penjual menjual peuyeum bendul, sebagai salah satu cara untuk melestarikan dan mempertahankan makanan khas dari daerah Bendul Purwakarta.

b. Peuyeum bendul didapat dari pengepul (bandar).

c. Harga beli dari pengepul (bandar) Rp. 6.000/Kg

d. Pengepul mengirimkan peuyeum kepada penjual dalam seminggu sekali.

e. Peuyeum dijual dengan harga $\mathrm{Rp}$. $10.000 / \mathrm{Kg}$

f. Banyaknya pembeli ketika libur panjang seperti libur lebaran, tahun baru. Tetapi ketika adanya pandemic covid-19 menjadi sepi pengunjung.

g. Ketahanan peuyeum kurang lebih 5-6 hari.

h. Penjualan masih dijual secara offline atau hanya dijual di kios-kios.

i. Kurang gencar melakukan pemasaran.

j. Pembeli sebagian besar adalah orang dewasa yang memiliki usia diatas 30 tahun.

k. Penjualan mengalami penurunan hingga $20-40 \%$

\subsection{Analisis SWOT}

Analisis SWOT berasal dari kata kekuatan (strengths), kelemahan (weaknesses), peluang (opportunities), dan ancaman (threats). Faktor internal perusahaan meliputi kekuatan serta kelemahan perusahaan. Sedangkan, faktor eksternal perusahaan meliputi peluang serta ancaman perusahaan.

1) Kekuatan (Strength) yang dimiliki penjual peuyeum bendul adalah :

a. Motivasi untuk mempertahankan dan memajukan makanan khas yaitu peuyeum bendul.

b. Kerjasama yang baik antara penjual dengan pemasok agar mendapat bahan baku yang berkualitas.

c. Memiliki pelanggan tetap.

d. Harga peuyeum yang masih terjangkau.

2) Kelemahan (Weaknesses) yang dimiliki penjual peuyeum bendul adalah : 
a. Banyaknya penjual peuyeum di luar daerah Kabupaten Purwakarta.

b. Kurangnya penguasaan dalam strategi pemasaran yang kreatif seperti mengabaikan branding, packaging, diferensiasi produk, serta promosi.

c. Tidak ada laporan pemisahan keuangan antara keuangan bisnis dan keuangan keluarga.

d. Kurangnya modal.

3) Peluang (Opportunities) yang dimiliki penjual peuyeum bendul adalah :

a. Peuyeum dapat melakukan diferensiasi produk yang dijadikan sebagai oleh-oleh dari Purwakarta.

b. Saat musim libur panjang banyak mendapatkan keuntungan.

c. Sebagian toko penjual peuyeum buka 24 jam setiap harinya, sehingga dapat memudahkan para pembeli yang melintas di jalan Sukatani masih dapat memperoleh peuyeum.

d. Banyaknya permintaan produk dari pelanggan terutama peuyeum bendul.

4) Ancaman (Threats) yang dimiliki penjual peuyeum bendul adalah:

a. Adanya peuyeum dari daerah lain yang lebih mudah untuk diperoleh.

b. Kurangnya minat berwirausaha karena kehadiran pabrik di daerah purwakrta.

c. Munculnya produk impor yang lebih banyak diminati.

d. Belum tersedianya tempat untuk memproduksi olahan berbahan dasar peuyeum.

\subsection{Analisis Matriks SWOT}

Strategi berdasarkan analisis SWOT adalah sebagai berikut :

1) Strategi $\mathrm{SO}$

a. Pengembangan produk dan mempertahankan kualitas produk peuyeum bendul serta meningkatkan pelayanan dalam penjualan.

b. Memanfaatkan teknologi dalam memaksimalkan dan memperluas pemasaran untuk meningkatkan penjualan.

2) Strategi ST a. Melakukan diferensiasi produk berbahan dasar peuyeum bendul agar memperpanjang ketahan dan meningkatkan kualitas produk serta menciptakan keunggulan diantara pesaing

3) Strategi WO

a. Memperbaiki kualitas SDM dengan mengadakan pelatihan dan pengembangan terhadap teknologi yang berkembang saat ini.

b. Memperbaiki kemasan produk.

4) Strategi WT

a. Mulai melakukan kegiatan promosi dengan memanfaatkan media sosial sebagai media informatif tentang keunggulan peuyeum bendul.

b. Mengatur pengelolaan keuangan bisnis.

4.5 Strategi Pengembangan Bisnis

Dari beberapa hasil strategi yang didapatkan, dapat disimpulkan bahwa strategi yang harus segera dilakukan penjual peuyeum bendul yaitu :

1) Melakukan diferensiasi produk berbahan dasar peuyeum bendul, sehingga ketahanan peuyeum dapat bertahan lebih lama, dan meminimalisir kerugian akibat peuyeum yang tidak terjual karena busuk.

2) Memperbaharui kemasan peuyeum agar memiki daya tarik sekaligus memperkuat branding produk tersebut.

3) Melakukan penjualan atau promosi melalui media sosial. Di era digital ini, kegiatan mempromosikan dan menjual barang/jasa diberi kemudahan serta akses yang mudah untuk dijangkau oleh semua orang.

4) Mengelola keuangan dengan baik. Para pelaku usaha harus memahami bagaimana mengatur arus kas agar tetap lancar.

\section{Kesimpulan}

Hasil penelitian penulis dari analisis dan pembahasan tentang Strategi Pengembangan Bisnis Penjual Peuyeum Bendul dapat ditarik beberapa kesimpulan, antara lain :

a. Hasil penelitian menunjukkan bahwa ditemukan analisis faktor internal penjual peuyeum bendul. Pertama faktor kekuatan (strengths) adalah motivasi untuk 
melestarikan makanan khas bendul, rantai pasok yang baik, memiliki pembeli loyal, harga terjangkau. Kedua, ditemukan juga analisis faktor internal penjual peyeum bendul berupa kelemahan (weaknesses) yaitu tidak ada variasi produk peuyeum, kurangnya modal, lokasi penjualan tidak strategis, strategi pemasaran monoton, manajemen keuangan yang buruk.

b. Hasil penelitian menunjukkan bahwa ditemukan analisis faktor eksternal penjual peuyeum bendul. Pertama, faktor Peluang (opportunities) produk bisa dikembangkan, terdapat teknologi untuk mengelola keuangan dan mengoptimalkan pemasaran.

c. Berdasarkan hasil analisis SWOT, strategi pengembangan bisnis yang harus dilakukan penjual peuyeum bendul adalah diferensiasi produk berbahan dasar peuyeum bendul, pengembangan kemasan terhadap penjualan peuyeuem bendul, pengembangan penjualan peuyeum bendul melalui media sosial, dan pengelolaan keuangan bisnis penjual peuyeum bendul.

\section{Saran}

Berdasarkan hasil dari kesimpulan maka saran dari penulis untuk strategi pengembangan bisnis penjual peuyeum bendul adalah sebagai berikut :

a. Manfaatkan teknologi sebagai sarana belajar untuk memperbaiki pengelolaan keuangan dan pemasaran.

b. Kegiatan oprasional harus lebih efisien.

c. Buat packaging dan branding yang lebih menarik untuk menarik minat konsumen.

\section{Daftar Pustaka}

Anggraeni, N., Turgarini, D., \& Miftah, R. (2017). Strategi Peningkatan Penjualan Di Suis Butcher Cabang Setiabudi. Gastronomy Tourism Journal, 3(2), 27-36. ISSN: 2774-6186.

Asnawi, M. (2013). Karakteristik Tape Ubi Kayu (Manihot Utilissima) Melalui Proses Pematangan dengan Penggunaan Pengontrol Suhu. Jurnal Bioproses Komoditas Tropis, 1(2), 56-66. ISSN: 23384670.
David, F. R. (2019). Manajemen Strategik: Suatu Pendekatan Keunggulan Bersaing-Konsep (15 ed.). Penerjemah Novita Puspasari, Liza Nurbani P. Jakarta: Salemba Empat.

Fatimah, F. N. D. (2020). Teknik Analisis SWOT Pedoman Menyusun Strategi Yang Efektif \& Efisien Serta Cara Mengelola Kekuatan \& Ancaman. Yogyakarta: Anak Hebat Indonesia.

Hidayat, S., \& Prasetyo, A. D. (2018). Perancangan Media Komunikasi Visual Peuyeum Bendul Dari Purwakarta. eProceedings of Art \& Design, 5(1), 267283. ISSN: 2355-9394.

Pratiwi, R. (2018). Strategi Pengembangan Usaha Rengginang Pulut Dengan Metode Analisis SWOT (Studi Kasus Usaha Rengginang Pulut CV. UUL Jaya Di Desa Kebun Lada Kecamatan Hinai Kabupaten Langkat). Skripsi Fakultas Ekonomi dan Bisnis Islam, Universitas Islam Negeri Sumatera Utara. Medan.

Revida, E., Gaspersz, S., Uktolseja, L. J., Nasrullah, N., Warella, S. Y., Nurmiati, N., Alwi, M. H., Simarmata, H. M. P., Manurung, T., \& Purba, R. A. (2020). Pengantar Pariwisata (J. Simarmata (ed.)). Medan: Yayasan Kita Menulis.

Setyorini, H., Effendi, M., \& Santoso, I. (2016). Analisis Strategi Pemasaran Menggunakan Matriks SWOT dan QSPM (Studi Kasus: Restoran WS Soekarno Hatta Malang). Jurnal Teknologi dan Manajemen Agroindustri, 5(1), 46-53. https://doi.org/10.21776/ub.industria.2016. 005.01 .6

Supiandi, A. (2020). Peuyeum dan Colenak Bendul Oleh-Oleh Khas Purwakarta Yang Melegenda. iNewsJabar.id. Diambil dari https://www.google.co.id/amp/s/jabar.inew s.id/amp/berita/peuyeum-dan-colenakbendul-oleh-oleh-khas-purwakarta-yangmelegenda

Wibowo, D. H., \& Arifin, Z. (2015). Analisis Strategi Pemasaran Untuk Meningkatkan Daya Saing Umkm (Studi pada Batik Diajeng Solo). Jurnal Administrasi Bisnis, 29(1), 59-66. 